\title{
Implementasi Karakter Siswa Dalam Pembelajaran Terpadu di Sekolah Dasar
}

\section{Riddo Imam Muttaqin*1, Valentino Febrianto Lili Putra' ${ }^{2}$, Rieke Nopellia Dwiyanty ${ }^{3}$, Rosy Aprilia Fauziyah $^{4}$, Ani Nur Aeni ${ }^{5}$}

\author{
1,2,3,4,5Pendidikan Guru Sekolah Dasar, Universitas Pendidikan Indonesia, Indonesia \\ Email: ${ }^{1}$ riddo.imammuttaqin@upi.edu, ${ }^{2}$ valentinoflp13@upi.edu, ${ }^{3}$ riekenopellia@upi.edu, \\ ${ }^{4}$ rosyapriliaf@upi.edu, ${ }^{5}$ aninuraeni@upi.edu
}

\begin{abstract}
Abstrak
Penelitian ini bertujuan untuk mendeskripsikan berbagai strategi yang dilakukan sekolah dalam mengimplementasikan karakter siswa dalam pembelajaran terpadu di sekolah dasar penelitian ini merupakan penelitian deskriptif dengan menggunakan angket survey. Penelitian ini dilakukan di Sekolah Dasar dengan subjek guru. Metode yang digunakan dalam penelitian ini ialah Kualitatif yaitu mendeskripsikan, menguraikan, serta menggambarkan upaya guru dalam melaksanakan implementasi karakter siswa dalam pembelajaran terpadu di sekolah dasar. Pengumpulan data dilakukan melalui survey kuesioner yang disebarluaskan kepada beberapa guru di sekolah dasar. Teknik pemeriksaan keabsahan data yang digunakan adalah survey kuesioner atau angket. Hasil penelitian menunjukkan bahwa guru sudah baik dalam memahami pembelajaran terpadu dan karakteristik dari peserta didik yang diwujudkan dalam pengimplementasian dari pembelajaran terpadu terhadap karakteristik peserta didik, baik melalui kegiatan pembelajaran, pembiasaan, budaya sekolah, dan lain-lain.
\end{abstract}

Kata kunci: Implementasi, Karakter, Pembelajaran Terpadu.

\section{Implementation of Student Character in Integrated Learning in Elementary Schools}

\begin{abstract}
This research aims to describe various strategies carried out by schools in implementing the character of students in integrated learning in elementary school this research is descriptive research using survey questionnaires. The study was conducted in elementary school with the subject of the teacher. The method used in this study is qualitative, which describes, describes, and describes the efforts of teachers in implementing the implementation of student character in integrated learning in elementary school. Data collection is done through a questionnaire survey disseminated to several teachers in elementary schools. The data validity examination technique used is a questionnaire survey or questionnaire. The results showed that teachers are already good in understanding integrated learning and the characteristics of learners embodied in the implementation of integrated learning to the characteristics of learners, both through learning activities, and others.
\end{abstract}

Keywords: Implementation, Character, Integrated Learning.

\section{PENDAHULUAN}

Rencana pemerintahan dalam pengembangan pendidikan karakter sangat pantas didukung seluruh komponen bangsa termasuk sekolah dan perguruan tinggi. pendidikan karakter ini sangat dibutuhkan untuk untuk membangun bangsa Indonesia agar bangkit dari keterpurukan moral dan sosial yang berdampak luas. Pendidikan karakter siswa merupakan suatu system penanaman nilai-nilai karakter kepada peserta didik yang dapat meliputi kesadaran, pemahaman, kepedulian dan komitmen. Pendidikan mempunyai tugas menyiapkan sumber daya manusia untuk pembangunan. Langkah pembangunan selalu diupayakan seirama dengan tuntutan zaman. Perkembangan zaman selalu memunculkan persoalan-persoalan baru yang tidak pernah terpikirkan sebelumnya. Seiring kemajuan ilmu dan teknologi berdampak pada kehidupan manusia yang selalu mengalami perubahan, baik dari segi ekonomi, moralitas, serta pola hidup. Perubahan-perubahan itu terjadi akibat banyaknya tuntutan dan keinginan baik dari lingkungan keluarga maupun dari pihak luar.[1] Penanaman karakter siswa di Sekolah Dasar dibentuk melalui pembelajaran terpadu, yang dimana pembelajaran terpadu ini dapat terintegrasikan dalam pembelajaran setiap mata pelajaran yang ada di sekolah. Materi yang berkaitan dengan karakter siswa seperti norma atau nilai-nilai pada setiap mata pelajaran dapat dikembangkan. Dengan 
adanya pembelajaran yang memiliki nilai-nilai karakter tidak hanya pada tataran kognitif saja tetapi menyentuh pada internalisasi dan pengalaman nyata dalam kehidupan siswa sehari-hari.

Karakteristik peserta didik merupakan aspek-aspek atau kualitas perseorangan peserta didik yang terdiri dari minat, perilaku, motivasi belajar, gaya belajar kemampuan berfikir, serta kemampuan awal yang dimiliki[2]. pembinaan karakter peserta didik wajib dilakukan secara dini di Sekolah Dasar, karena Sekolah Dasar merupakan periode pendidikan yang sangat penting buat menentukan arah pengembangan potensi peserta didik. Sekolah dasar adalah lingkungan pendidikan formal pertama yang dialami oleh anak. Di sekolah dasar anak diperkenalkan dan ditanamkan dasar-dasar nilai seperti kejujuran, kesusilaan, kesopanan, tata krama, budi pekerti, etika dan moral. Dari nilai dasar itulah diharapkan akan menjadikan anak tumbuh menjadi anak yang cerdas otaknya, bersih hatinya, dan terampil tangannya, tiga komponen pendidikan tersebut ada dalam diri siswa yaitu aspek kognitif, afektif, dan psikomotor. Oleh karena itu sekolah dasar memiliki peran penting dalampembangunan fondasi karakter individu[3]. Atas dasar itu, maka seluruh aktivitas pendidikannya harus mampu memfasilitasi penanaman dan pengembangan nilai peserta didik agar berbudi pekerti yang luhur. Oleh karena itu, kekeliruan dalam pendidikan nilai-moral di sekolah dasar akan berdampak panjang pada kehidupan moral individu di masa depannya.

Sekolah sebagai lembaga pendidikan bertanggung jawab terhadap pembentukan karakter siswa (character building). Oleh karena itu, karakter tidak hanya tumbuh dan berkembang pada setiap individu manusia, tetapi juga pada organisme atau institusi pendidikan. Karakter siswa tidak mungkin tumbuh dan berkembang jika sekolah tersebut tidak berkarakter [3]. Dengan kata lain, hanya pada institusi pendidikan berkarakterlah, peserta didik akan tumbuh dan berkembang sebagai manusia yang berkarakter.

Pentingnya akan karakter disampaikan oleh beberapa pendapat seperti menurut Roosevelt[3], bahwa mendidik seseorang dalam aspek kecerdasan otak tanpa aspek moral melahirkan ancaman bagi masyarakat, menurut King Jr. menjelaskan bahwa kecerdasanyang berkarakter adalah tujuan akhir pendidikan dan menurut Covey [3] menjelaskan bahwa bahayanya sedikit ilmu pengetahuan bagi manusia, namun lebih berbahaya banyak pengetahuan namun tidak berkarakter, karena tidak adanya karakter akan menyebabkan hilangnya generasi penerus suatu bangsa, pendidikan seharusnya menghasilkan manusia seutuhnya yang seimbang.

Penerapan program pendidikan karakter di sekolah telah meningkatkan prestasi akademik yang lebih tinggi, penurunan siswa yang putus sekolah, dan sedikit perilaku berisiko siswa. Implementasi pendidikan karakter telah meningkatkan perilaku siswa, seperti mengurangi buly, konflik dan kekerasan[3]. Sehingga suasana sekolah memunculkan siswa yang akan lebih simpatik, toleran, baik hati, penyayang, dan pemaaf Sementara[4].

Fenomena tersebut menjadikan pembinaan karakter siswa pada satuan pendidikan di Indonesia dewasa ini merupakan suatu kemutlakan untuk dilaksanakan. Apalagi dikaitkan dengan adanya beberapa penyimpangan yang dilakukan siswa seperti menurunnya rasa tanggung jawab, kejujuran, dan berbahasa santun. Bahkan dalam kurun waktu 9 tahun, dari 2011 sampai 2019, ada 37.381 pengaduan kekerasan terhadap anak. Sementara untuk Bullying baik di pendidikan maupun sosial media, angkanya mencapai 2.473 laporan yang masuk kepada KPAI dan trennya terus meningkat, laporan pada saat ini terdapat 7.400 anak usia SD terpapar narkoba berdasarkan informasi Direktorat Narkoba Polri Tahun 2020. Perilaku tidak disiplin juga sering ditemui di lingkungan sekolahdasar. Sebagai contoh perilaku tidak disiplintersebut antaralain datang ke sekolah tidak tepat waktu, tidak memakai seragam,duduk atau berjalan dengan seenaknya menginjak tanaman yang jelas-jelas sudah dipasang tulisan "dilarang menginjaktanaman", membuang sampah sembarangan,mencorat coret dinding sekolah, membolos sekolah, mengumpulkan tugas tidak tepat waktu,danlain-lain[5]. Terjadinya perilaku menyimpangdi sekolah menunjukkan telah terjadipermasalahan serius dalam hal pendidikan karakter. Munculnya berbagai penyimpanganmenunjukkan karakter baru sebatas pengetahuanyangtidak membawa dampak positif terhadap perubahan perilaku siswa sehari-hari. Pada dasarnya siswa tahu bahwa perilakunya tidak benar tetapi mereka tidak memiliki kemampuanuntuk membiasakan diri menghindari perilakuyang salah tersebut. Hal ini bisajadi diakibatkan pendidikan karakter baru sebatas tahap pengetahuan saja (knowing), belumsampai pada perasaan dan perilaku yang berkarakter. Sekolah mestinya membantu siswa untuk mengenal, memahami, menginternalisasi, dan berusaha untuk menerapkan nilai-nilai dalam kehidupan sehari-hari.[6]

Proses pembelajaran lebih banyak mengajarkan siswa pengetahuan verbalistik yangkurang mempersiapkan siswa agar mampumenghadapi kehidupan sosial yang akan mereka temui.Makna pendidikan yang syarat dengan nilai-nilai moral bergeser pada pemaknaan pengajaran yang berkonotasi sebagai transfer ilmu pengetahuan, pendidikan "cenderung menitikberatkan pada hapalan dan mendapatkan nilai bagus serta mengabaikan pengembangansikap dan karakter warga Negara [3]. Senada dengan itu, pendidikan selama ini lebih diarahkan pada peningkatan kemampuan otak kiri sebaliknya kemampuan otak kanan kurang ditumbuhkembangkan[7]. Bahkan dapat dikatakan tidak pernah dikembangkan secara 
sistematis. Dengan kata lain, jika meminjam istilah Preire praktik pendidikan formal saat ini dapat dikatakan memenuhi kriteria banking system of educationyang tidak dapat membebaskan peserta didik dari ketertindasan yang mengakibatkan pendidikan pada tingkat dasar cenderung berorientasi pada pengajaran yang mengutamakan penguasaan materi pelajaran (content oriented) dari pada berorientasi kebutuhan perkembangan siswa (student oriented) [3]. Penyebab utama terjadinya krisis moral dan karakter di kalangan peserta didik, lulusan, pendidik, bahkan pengelola pendidikan, adalah terjadinya dikotomisasi yaitu pemisahan secara tegas antara pendidikan intelektual di satu pihak dan pendidikan nilai di lain pihak [8]; [9]; [10]; [11].

Kondisi demikian menjadi daya tarik bagi peneliti untuk melaksanakan penelitian terkait pembelajaran yang mampu membina karakter siswa. Pembelajaran terpadu dipandang merupakan salah satu cara untuk membina karakter siswa, karena pembelajaran terintegrasi merupakan pendekatan belajar yang melibatkan beberapa bidang studi untuk memberikan pengalaman yang bermakna pada anak. Dengan pengalaman yang bermakna akan melahirkan sifat mulia kemanusiaan agar manusia sebagai makhluk tertinggi dimuka bumi ini tidak terpeleset jatuh menjadi makhluk yang tidak manusiawi[3].

\section{METODE PENELITIAN}

Penelitian ini menggunakan penelitian deskriptif dengan menggunakan pendekatan kualitatif. Metode penelitian kualitatif biasanya mencakup wawancara dan observasi, tetapi mungkin juga termasuk studi kasus, survei, dan analisis historis dan dokumen. Penelitian kualitatif adalah payung istilah yang digunakan untuk merujuk pada desain perspektif teoretis seperti penelitian narasi, fenomenologi, penelitian tindakan, studi kasus, etnografi, penelitian sejarah, dan analisis konten[12] Penelitian ini bertujuan untuk mendeskripsikan implementasi karakter siswa dalam pembelajaran terpadu di sekolah dasar. Penelitian ini dilakukan di Sekolah Dasar daerah Sumedang. Teknik pengumpulan data yang digunakan dalam penelitian ini adalah berupa angket yang di sebarkan ke guru sekolah dasar di daerah Sumedang. Kuesioner atau angket adalah suatu teknik pengumpulan informasi yang memungkinkan analis mempelajari sikap-sikap, keyakinan, perilaku, dan karakteristik beberapa orang utama di dalam organisasi yang bisa terpengaruh oleh sistem yang diajukan atau oleh sistem yang sudah ada. Pengumpulan data angket/ kuisoner adalah suatu alat pengumpul data yang berupa serangkaian pertanyaan tertulis yang diajukan kepada subyek untuk mendapatkan jawaban secara tertulis juga. Dalam menggunakan angket kelompok kita mengajukan pertanyaan yang berupa pendapat mereka terhadap karakter siswa pada pembelajaran terpadu, dan penerapan guru kepada siswa dalam pembelajaran terpadu. Kemudian, angket juga untuk melihat implementasi karakter siswa dalam pembelajaran terpadu. Untuk memperoleh data yang dapat dipertanggungjawabkan secara ilmiah, dalam penelitian ini dilakukan keabsahan data. Dalam penelitian ini teknik pemeriksaan keabsahan data yang digunakan adalah survey kuesioner

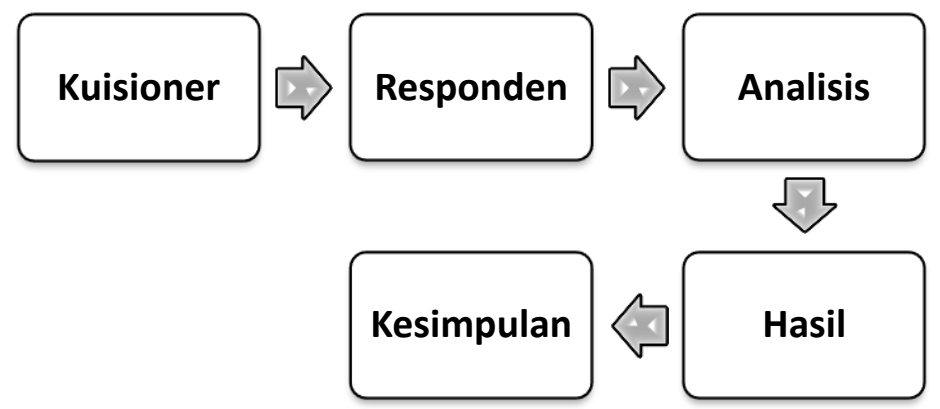

Gambar 1. Flowchart Metode Penelitian Yang Digunakan

\section{HASIL DAN PEMBAHASAN}

Penelitian yang dilaksanakan untuk mengetahui bagaimana implementasi karakter pada siswa melalui pembelajaran terpadu di sekolah dasar ini dilakukan dengan menyebarkan angket kepada beberapa guru sekolah dasar yang berada dari berbagai macam daerah sesuai dengan asal dari anggota peneliti ini. Dari angket yang telah peneliti sebarluaskan, didapatkan beragam hasil jawaban dari para guru terkait topik pembahasan pada penelitian ini. Berikut merupakan hasil data angket yang diisi oleh beberapa guru dalam kegiatan penelitian ini.

Berdasarkan jawaban dari beberapa pertanyaan pada angket yang peneliti sebarluaskan kepada beberapa guru, pengetahuan guru terhadap pemahaman dan makna dari pembelajaran terpadu itu sendiri sudah sudah dialami, hal ini dibuktikan dengan persentase yang besar, yakni sebesar 100\%. Kemudian beberapa guru yang mengisi angket pula sudah memahami karakteristik serta fungsi dari pembelajaran terpadu, hal in dibuktikan 
dengan persentase yang besar pula, yakni sebesar 100\%. Selanjutnya, beberapa guru sudah memahami dalam menentukan kegiatan-kegiatan pembelajaran melalui karakter peserta didik, namun disisi lain masih terdapat pula guru yang belum memahami hal tersebut, hal ini dibuktikan dengan jumlah persentase sebesar $90 \%$ guru sudah memahami dan 10\% belum memahami hal tersebut. Kemudian, beberapa guru pula sudah mengetahui fungsi dari Pendidikan karakter, hal ini dibuktikan dengan persentase guru yang sudah memahami hal tersebut sebesar 100\%. Dalam memberikan umpan balik yang dilakukan guru kepada peserta didik agar memiliki karakter tersendiri pada diri peserta didik, sebagian besar guru sudah melakukannya, hal ini dibuktikan dengan jumlah persentasi $80 \%$ guru yang sudah melakukan dan $20 \%$ guru yang belum melakukan hal tersebut. Kemudian sebagian besar guru pula sudah mengetahui tentang penguatan Pendidikan karakter yang perlu dilakukan kepada peserta didik, serta untuk melakukan hal itu sebagian guru pula sudah merencanakan pembelajaran yang ideal untuk peserta didik sesuai dengan kurikulum yang diterapkan. Dalam hal ini, para guru pun sependapat bahwasannya penting untuk diterapkannya Pendidikan Karakter untuk peserta didik di Sekolah Dasar.

Tabel 1. Hasil Observasi melalui Googleform

\begin{tabular}{|c|c|c|c|}
\hline & PERTANYAAN & SUDAH & BELUM \\
\hline 1. & $\begin{array}{l}\text { Apakah bapak/Ibu sudah mengerti tentang } \\
\text { pembelajaran terpadu? }\end{array}$ & $100 \%$ & - \\
\hline 2. & $\begin{array}{l}\text { Apakah Bapak/Ibu sudah mengerti makna } \\
\text { dari pembelajaran terpadu? }\end{array}$ & $100 \%$ & - \\
\hline 3. & $\begin{array}{l}\text { Apakah Bapak/Ibu sudah mengerti tentang } \\
\text { karakteristik pembelajaran terpadu? }\end{array}$ & $100 \%$ & - \\
\hline 4. & $\begin{array}{l}\text { Apakah Bapak/Ibu mengetahui fungsi } \\
\text { pembelajaran terpadu? }\end{array}$ & $100 \%$ & - \\
\hline 5. & $\begin{array}{l}\text { Apakah Bapak/Ibu sudah mengerti dalam } \\
\text { menentukan kegiatan-kegiatan pembelajaran } \\
\text { melalui karakter peserta didik? }\end{array}$ & $90 \%$ & $10 \%$ \\
\hline 6. & $\begin{array}{l}\text { Apakah sudah Bapak/Ibu mengetahui fungsi } \\
\text { pendidikan karakter? }\end{array}$ & $100 \%$ & - \\
\hline 7. & $\begin{array}{l}\text { Apakah Bapak/Ibu sudah mengerti dalam } \\
\text { memberikan umpan balik pada siswa agar } \\
\text { memiliki karakter sendiri pada diri peserta } \\
\text { didik? }\end{array}$ & $80 \%$ & $20 \%$ \\
\hline 8. & $\begin{array}{l}\text { Apakah Bapak/ibu sudah mengerti peran } \\
\text { pendidikan formal mau pun non formal } \\
\text { dalam pendidikan karakter? }\end{array}$ & $100 \%$ & - \\
\hline 9. & $\begin{array}{l}\text { Apakah Bapak/ibu sudah mengetahui } \\
\text { tentang penguatan pendidikan karakter? }\end{array}$ & $80 \%$ & $20 \%$ \\
\hline & $\begin{array}{l}\text { Apakah bapak/ibu sudah merencanakan } \\
\text { pembelajaran yang ideal dari kurkulum } \\
\text { yang di terapkan? }\end{array}$ & $70 \%$ & $30 \%$ \\
\hline & $\begin{array}{l}\text { Apakah bapak/ibu setuju dengan adanya } \\
\text { pendidikan karakter diterapkan pada peserta } \\
\text { didik Sekolah Dasar? }\end{array}$ & $100 \%$ & - \\
\hline 12. & $\begin{array}{l}\text { Apakah Bapak/Ibu sudah mengetahui dalam } \\
\text { menentukan karakter peserta didik dapat } \\
\text { melalui pembelajaran terpadu? }\end{array}$ & $80 \%$ & $20 \%$ \\
\hline
\end{tabular}

PERTANYAAN JAWABAN

1. Apa yang dilakukan Bapak/Ibu dalam 1. Mengaitkan pembelajaran dengan nilaimengembangkan karakter peserta didik nilai islami. Seperti membaca doa melalui pembelajaran terpadu? sebelum belajar, memberika hadisthadist pendek, mengaitkan konten pembelajaran dengan nilai-nilai islam. Memberikan model pembelajaran yang berorientasi untuk melatih soft skill siswa, seperti berdiskusi, bergotong royong dll. 
2. Selalu mengaitkan materi pembelajaran dengan nilai-nilai karakter yang harus dimiliki oleh setiap anak. Contohnya anak melalui pengamatan, percobaan, melalui wawancara, penugasan individu maupun kelompok.

3. Dengan cara pendekatan terhadap peserta didik.

4. Menerapkan pembiasaan dalam proses pembelajaran. Membaca doa, melafalkan pancasila, budaya 3 kata ajaib (maaf, tolong, terima kasih), bekerja dalam kelompok.

5. Dengan pembelajaran terpadu bisa mengembangkan karakter peserta didik melalui beberapa mata pelajaran yang dijadikan satu. Dengan keterhubungan mata pelajaran tersebut akan menjadikan pembelajaran bermakna, dengan begitu tidak akan sulit ketika mengembangkan karakter peserta didik.

6. Dalam pembelajaran terpadu terdapat beberapa karakter yg harus peserta didik capai, dalam pembelajaran terpadu pun terdapat beberapa materi yg dikemas menjadi satu kesatuan. Misalnya karakter yg dicapai yaitu percaya diri dan materi yg sedang diajarkan tentang bercerita atau membuat laporan sederhana. Guru menugaskan untuk membuat laporan sederhana yg kemudian hasilnya di presentasikan. Dengan peserta didik mempresentasikan, guru dapat mengetahui percaya diri pada peserta didik sampai mana.

7. Menggunakan pendekatan kurikulum terpadu sesuai kebutuhan dilapangan.

8. Menerapkan proses pembelajaran terpadu dalam pembelajaran dengan disisipkan nilai-nilai karakter

9. Meningkatkan akhlak luhur para siswa adalah tanggung jawab semua guru, semua guru harus menjadi teladan yang berwibawa, tujuan utuh pendidikan adalah membentuk sosok siswa secara utuh, pencapaian pendidikan harus mencakupi dampak instruksional dan dampak pengiring.

Selalu memberikan pemahaman dan menanamkan karakter-karakter yang baik dalam pembelajatan terpadu.

2. Bagaimana tanggapan bapak/ibu tentang pengaruh pembelajaran terpadu terhadap pembangunan karakter peserta didik?
1. Belum sepenuhnya bisa membangun karakter anak, karena karakter anak lebih banyak dibangun dari kegiatan di luar pembelajaran. Terlebih lagi guru masih kesulitan dalam menyampaikan materi dengan target dan tuntutan tertentu, sehingga terkadang 
mengabaikan nilai-nilai karakter anak.

2. Pengaruh pembelajaran terpadu pada karakter siswa tergantung lingkungan rumah siswa. Karena pembelajaran terpadu di sekolah akan sangat lebih berpengaruh kepada karakter siswa bila lingkungan rumah membantu juga.

3. Harus menjadikan conto kepada peserta didik.

4. Sebenarnya memiliki banyak pengaruh positif, jika dikelas rendah dirasa ada lebih mudah diterapkan dibandingkan di kelas tinggi.

5. Berpengaruh karena dengan adanya pembelajaran terpadu guru dapat membangun karakter peserta didik dari berbagai mata pelajaran yang dijadikan satu yang kemudian ditransfer kepada siswa dan siswa dapat mengimplementasikan dikehidupan sehari-hari.

6. Pengaruh tidaknya tergantung kemampuan guru dalam mengemas materi dan mengaitkan karakter yg perlu dicapai oleh peserta didik.

7. Berpengaruh banyak terhadap pembangunan peserta didik.

8. Sangat bagus, dengan pembelajaran terpadu tidak hanya ketercapaian pembelajaran saja tetapi karakter siswa juga tercapai.

9. Proses pembelajaran pendidikan karakter secara integralistik (terpadu) bisa dibenarkan karena sejauh ini muncul keyakinan bahwa anak akan tumbuh dengan baik jika dilibatkan secara alamiah dalam proses belajar.

3. Bagaimana bentuk pengaruh pembelajaran terpadu terhadap implementasi karakteristik peserta didik?
Pembelajaran terpadu menjadi salah satu sarana untuk membangun karakter peserta didik

1. Melalui kegiatan pembelajarannya yang kerap dikaitkan dengan nilai-nilai pancasila dan norma-norma dalam kehidupan sehari-hari.

2. Pembelajaran terpadu merupakan pembelajaran yang secara luas dan utuh diberikan kepada anak dengan begitu pada penerapan karakter siswa akan lebih mudah memahami dan mudah menerapkan di lingkungannya. Namun tetap harus ada dukungan dari lingkungan juga.

3. Pendidik kan sebagai fasilitator dalam kegiatan ngajar mengajar untuk membentuk karakter siswa.

4. Siswa lebih aktif dan proses pembelajaran menjadi lebih sederhana karna tidak ada sekat antarmata 
pelajaran jadi lebih efisien, siswa lebih bertanggungjawab atas tugasnya terutama saat bekerja dalam kelompok.

5. Dengan pembelajaran terpadu siswa dapat mengimplementasikan hasil belajarnya pada kehidupan sehari-hari.

6. Peserta didik semakin semangat dalam belajar, materi yg diajarkan mudah dipahami anak, ketika karakter peserta didik sudah muncul pada saat belajarpun akan lebih disiplin dan percaya diri.

7. Terlihat peningkatan karakteristik peserta didik dan memudahkan guru menganalisis setiap karakter siswa.

8. Dalam proses pembelajaran menjadi lebih efektif, tidak menjadikan siswa jenuh sehingga proses pembelajaran juga lebih bermakna.

9. Dikatakan bermakna karena dalam pembelajaran terpadu, anak akan memahami konsep yang dipelajari melalui pengalaman langsung dan menghubungkannya dengan konsep lain yang sudah dipahami anak melalui kesempatannya mempelajari apa yang berhubungan dengan tema atau peristiwa otentik (alami). Memberikan pengalaman yang bermakna kepada peserta didik

Dalam hasil angket lainnya didapatkan pula bahwasannya penting juga bagi guru untuk Mengaitkan pembelajaran dengan nilai-nilai islami atau budi pekerti yang luhur. Selalu mengaitkan materi pembelajaran dengan nilai-nilai karakter yang harus dimiliki oleh setiap anak. Menerapkan pembiasaan dalam proses pembelajaran. Dengan pembelajaran terpadu bisa mengembangkan karakter peserta didik melalui beberapa mata pelajaran yang dijadikan satu. Dalam pembelajaran terpadu terdapat beberapa karakter yg harus peserta didik capai, dalam pembelajaran terpadu pun terdapat beberapa materi yg dikemas menjadi satu kesatuan. Kemudian dalam fakta dilapangan mengenai pengaruh pembelajaran terpadu terhadap pembangunan karakter peserta didik pada data yang didapat melalui pendapat para guru yang cukup beragam, secara garis besar bahwa Pengaruh pembelajaran terpadu pada karakter siswa tergantung lingkungan rumah siswa. Berpengaruh karena dengan adanya pembelajaran terpadu guru dapat membangun karakter peserta didik dari berbagai mata pelajaran yang dijadikan satu yang kemudian ditransfer kepada siswa dan siswa dapat mengimplementasikan dikehidupan sehari-hari. Sangat bagus, dengan pembelajaran terpadu tidak hanya ketercapaian pembelajaran saja tetapi karakter siswa juga tercapai. Kemudian mengenai implementasi karakteristik peserta didik terhadap pengaruh dari pembelajaran terpadu itu sendiri, didapatkan bahwasannya. Pembelajaran terpadu merupakan pembelajaran yang secara luas dan utuh diberikan kepada anak dengan begitu pada penerapan karakter siswa akan lebih mudah memahami dan mudah menerapkan di lingkungannya. Kemudian dalam fakta dilapangan mengenai pengaruh pembelajaran terpadu terhadap pembangunan karakter peserta didik pada data yang didapat melalui pendapat para guru yang cukup beragam, secara garis besar bahwa Pengaruh pembelajaran terpadu pada karakter siswa tergantung lingkungan rumah siswa. Berpengaruh karena dengan adanya pembelajaran terpadu guru dapat membangun karakter peserta didik dari berbagai mata pelajaran yang dijadikan satu yang kemudian ditransfer kepada siswa dan siswa dapat mengimplementasikan dikehidupan sehari-hari.

\section{KESIMPULAN}

Setelah dilaksanakannya penelitian tentang Berdasarkan jawaban dari beberapa pertanyaan pada angket yang peneliti sebarluaskan kepada beberapa guru, pengetahuan guru terhadap pemahaman dan makna dari pembelajaran terpadu itu sendiri sudah sudah dialami, hal ini dibuktikan dengan persentase yang besar, yakni 
sebesar $100 \%$. Kemudian beberapa guru yang mengisi angket pula sudah memahami karakteristik serta fungsi dari pembelajaran terpadu, hal in dibuktikan dengan persentase yang besar pula, yakni sebesar 100\%. Kemudian dalam fakta dilapangan mengenai pengaruh pembelajaran terpadu terhadap pembangunan karakter peserta didik pada data yang didapat melalui pendapat para guru yang cukup beragam, secara garis besar bahwa Pengaruh pembelajaran terpadu pada karakter siswa tergantung lingkungan rumah siswa. Berpengaruh karena dengan adanya pembelajaran terpadu guru dapat membangun karakter peserta didik dari berbagai mata pelajaran yang dijadikan satu yang kemudian ditransfer kepada siswa dan siswa dapat mengimplementasikan dikehidupan sehari-hari.

\section{DAFTAR PUSTAKA}

[1] D. Salma, "Manajemen Majelis Taklim Sebagai Wadah Pemberdayaan Masyarakat Menuju Pendidikan Karakter (Studi Terhadap Model Pengelolaan Majelis Taklim Di Sulawesi Utara),” vol. 22, no. 2, pp. 184-206, 2009.

[2] N. Sari, "Guru yang Berwawasan Luas menjadi Pembentuk Karakter Peserta Didik," Osfpreprints, pp. $1-6,2021$.

[3] Y. Z. Ansori, "Pembinaan Karakter Siswa Melalui Pembelajaran Terpadu Di Sekolah Dasar," J. Educ. FKIP UNMA, vol. 6, no. $1, \quad$ pp. $\quad 177-186, \quad 2020$. https://www.ejournal.unma.ac.id/index.php/educatio/article/view/308/202.

[4] N. Istiqomah, "Nilai-nilai Pendidikan Karakter Pada Novel Sepatu Dahlan Karya Khrisna Pabichara Implikasinya Terhadap Karakter Disiplin Belajar Siswa", vol. 9. 2015.

[5] M. Anisa, “Analisis Metode Kepramukaan Dalam Pembentukan Karakter Disiplin Peserta Didik Melalui Kegiatan Ekstrakulikuler Pramuka," Jakarta FITK UIN Syarif Hidayatullah Jakarta, 2020. http://repository.uinjkt.ac.id/dspace/handle/123456789/54673.

[6] Y. Z. Ansori, "Menumbuhkan Karakter Hormat dan Tanggung Jawab Pada Siswa Di Sekolah Dasar,” J. Educ., vol. 7, no. 3, pp. 599-605, 2021, doi: 10.31949/educatio.v7i3.1120.

[7] Y. Z. Ansori, "Menumbuhkan Karakter Baik Melalui Peranan Guru Di Sekolah,” J. Cakrawala Pendas, vol. 4, no. 2, 2018, doi: 10.31949/jep.v4i2.1497.

[8] R. Desti, S. Narimo, A. Fathoni, L. E. Rahmawati, and C. Widiyasari, "Pembentukan Karakter Siswa Berorientasi Higher Order Thinking Skills (HOTS) di Sekolah Dasar," ELSE (Elementary Sch. Educ. Journal), vol. 4, no. 1, pp. 109-118, 2020.

[9] P. I. A. Dewi, "Penerapan Model Discovery Learning Terhadap Pembentukan Karakter Siswa yang Berorientasi Higher Order Thinking (HOTS) di Sekolah Dasar," Edukasi J. Pendidik. Dasar, vol. 1, no. 2, pp. 173-178, 2020, http://jurnal.stahnmpukuturan.ac.id/index.php/edukasi/article/view/922.

[10] L. Ersi, "Gambaran Pendidikan Karakter oleh Guru Sejarah dalam Menanamkan Nasionalisme Peserta Didik," vol. 4, pp. 1299-1308, 2020.

[11] I. Agama and I. Negeri, "Skripsi Diajukan Kepada Fakultas Tarbiyah Dan Ilmu Keguruan Iain Purwokerto Untuk Memenuhi Salah Satu Syarat Guna Memperoleh Gelar Sarjana Pendidikan (S.Pd) Program Studi Pendidikan Islam Anak Usia Dini Fakultas Tarbiyah Dan Ilmu Keguruan (Ftik) Pur," 2020.

[12] Y. Nurmalasari and R. Erdiantoro, "Perencanaan Dan Keputusan Karier: Konsep Krusial Dalam Layanan BK Karier,” Quanta, vol. 4, no. 1, pp. 44-51, 2020, doi: 10.22460/q.v1i1p1-10.497 